\title{
SUSTAINABILITY OF SOILS TO FIRES AS A FACTOR OF PRESERVATION THE SHAPE OF STEPPE PROTECTED AREAS
}

\author{
Lyudmila V. Galaktionova ${ }^{1,2}$, Anastasia V. Vasilchenko ${ }^{3}$ \\ ${ }^{1}$ Federal Scientific Centre of Biological Systems and Agrotechnologies of RAS, Russia \\ ${ }^{2}$ Orenburg State University, Russia \\ e-mail:anilova.osu@mail.ru \\ ${ }^{3}$ Tyumen State University, Russia \\ e-mail:teslya_nastya@mail.ru
}

Received: 19.04.2019. Revised: 26.05.2019. Accepted: 02.06.2019.

\begin{abstract}
Protected areas located in the steppe zone of Russia represent unique territories. Fires are a constant strong factor affecting the plant and soil components of ecosystems. The resistance of soils to fire in the conditions of semi-arid climate and hilly topography determines the speed of recovery of vegetation and soils in the steppe landscape. The study was devoted to the restoration of water-physical, physico-chemical and chemical properties of soils after the fire in 2014 on the site of the site «Burtinskaya Steppe» of the Orenburg State Nature Reserve (Russia). The study sites were represented by two polygons with burned and unburned (control) areas. The destruction of vegetation by fire contributed to the reduction of moisture reserves in the layer of 0-30 cm by more than $30 \%$ in the first years after the fire. For burning soils, there was a greater warming and migration of easily soluble salts and gypsum to the upper part of the soil profile. The most intense accumulation of $\mathrm{CaSO}_{4}$ and sodium salts was noted in the soils of polygon 1 . The study of the fire influence on the content of soil organic matter and nutrients demonstrated their significant reduction in the first two years of research. The restoration of phosphorus and potassium content to the level of control sites was noted by the end of three years of monitoring. The content of soil organic matter and nitrogen significantly exceeded the values in control sites. The conducted research has allowed drawing a conclusion about the ability of soils of steppe landscapes to restoration of stocks of biogenic elements after the fire. At the same time, changing the granulometric composition and migration of soil salts up the profile can contribute to the restructuring of plant communities and change the basic properties of the soil cover. The particular danger of changing the soils of steppe landscapes arises in the context of recurring fires and changing climate. The observed post-pyrogenic dynamics of soil processes indicate the need for a deep and comprehensive study of the impact of fires on the soil as a key link in the functioning of steppe ecosystems.
\end{abstract}

Key words: chernozem, consequences of fires, organic carbon, particle size distribution, steppe ecosystems, water-physical properties of soils

\section{Introduction}

In Eurasia, the largest areas of steppes are in Russia, Kazakhstan, Ukraine, Mongolia and China. In the territory of the steppe zone of the Russian Federation considerable areas of arable land were excluded from arable use and part of these steppe spaces is included in the structure of state reserves (Rusanov \& Shein, 2013; Pavleichik et al., 2016).

The main factor of anthropogenic impact on the protected areas was wildfire. Fires, as a factor in the evolution of landscapes, are widespread in the (sub)boreal, and (sub)tropical zones of Eurasia, Africa, America, and Oceania (Leys et al., 2018).

The interest in fire research has become global and interdisciplinary, due to the influences, interactions and feedback between fire systems, terrestrial and atmospheric systems in the context of human health and climate dynamics (Jia et al., 2015).
Soils are among the most valuable non-renewable resources on Earth. They support natural vegetation and ecosystems, are the largest terrestrial organic carbon stock and act as storage and filters for water. Assessing the destruction of aboveground plant organs by fire is critical for effectively prediction the response of the terrestrial ecosystem carbon and water cycle to future climate change (Santín \& Doerr, 2016).

Sometimes, wildfire is considered as one of the soil-forming factors. But it can also significantly change vegetation, increase soil erosion and even lead to desertification of previously fertile areas (Krawchuk et al., 2009). The problem of preservation of reference areas of zonal steppe types with their inherent biodiversity and appearance is urgent. Therefore, practical importance of a comprehensive study of the fire impact on steppe vegetation and soil increases. 
The purpose of this work was to study the restoration of water-physical, physico-chemical and chemical properties of the soils of the site «Burtinskaya steppe» of the Orenburg State Nature Reserve after the fire of 2014.

\section{Material and Methods}

The study was conducted in the site «Burtinskaya steppe» of the Orenburg State Nature Reserve, Orenburg region, Russia (Fig. 1). The study area was burned in August 2014. And data were collected one year later in October 2015 and 2016, and in September 2017 and 2018. Burned and unburned sites polygon №1 and №2 were approximately 30 $50 \mathrm{~m}$ apart from each other depending on the site. Polygon 1 included a burned site at $51.203408^{\circ} \mathrm{N}$, $56.679956^{\circ} \mathrm{E}$, and an unburned site at $51.203625^{\circ} \mathrm{N}$, $56.678886^{\circ} \mathrm{E}$. Polygon 2 contained a burned site at $51.210553^{\circ} \mathrm{N}, 56.737581^{\circ} \mathrm{E}$, and an unburned site at $51.203408^{\circ} \mathrm{N}, 56.679956^{\circ} \mathrm{E}$.

Samples were collected from sites where physiographical, topographical properties, parent material and plant cover were similar before the fire influence. The soil cover of the site is represented by calcic sceletic chernozem according to IUSS Working Group WRB (2015). From each site (burned/ unburned) within both polygons, samples were collected at five points (weighing at least $500 \mathrm{~g}$ ), and then mixed into a medium sample (weighing at least $2 \mathrm{~kg}$ ). From each site, soil samples were taken from several depths: $0-10 \mathrm{~cm}, 10-20 \mathrm{~cm}, 20-30 \mathrm{~cm}, 30$ $40 \mathrm{~cm}, 40-50 \mathrm{~cm}$. The comparison of soil properties was made between burned and unburned sites.

The soil bulk density was determined by the undisturbed soil core cylinder method according to Klute (1986). The total nitrogen was measured using the semi-micro Kjeldahl method, mobile potassium by the Peive's method, mobile phosphorus using the Kirsanov's method according to Vorobieva (1998). The cation exchange capacity (CEC) was determined by the $\mathrm{BaCl}_{2}$ displaced method according to Sparks et al. (1996). The soil $\mathrm{pH}$ was determined by the electrode method at a $1 / 5$ soil to water ratio. The total organic carbon (TOC) was analysed using the dichromate oxidation technique (Vorobieva, 1998).

\section{Results and Discussion}

The fire impact on the steppe ecosystem was manifested in the destruction of above-ground parts of plants, which affected the change of thermal and water regimes of soils. The results indicated stronger heating and cooling of the soils in the burned sites in summer and winter compared to unburned sites.
In conditions of subboreal climate and insufficient atmospheric moisture, the release of the soil surface from plant material leads to an increased soil moisture loss described in detail for this site in the first two years after the fire by Pavleichik et al. (2016). So, in the first year after the fire, the soil moisture reserve is significantly lower in the soils of both sites after the fire (polygon 1: $U=3.2, p=0.005$; polygon $2: \mathrm{U}=3.2, \mathrm{p}=0.005)$. The restoration of vegetation cover and steppe felt contributed to the erasure of differences in soil moisture reserves of burned and unburned sites by the end of three years in polygon 1 , and four years in polygon 2 . The different recovery rate of moisture reserves in the polygons is associated with the heterogeneity of soil properties. Our results are in accordance with data obtained by Shcherbyna et al. (2017) and Manning et al. (2017).

The increase in soil surface repellency is a consequence of the deposition of a thin film of carbonaceous substances of pyrogenic origin and hydrophobic nature (Coetsee et al., 2010). This contributes to a significant reduction in the rate of water filtration from the soil surface by $15 \%$ and $22 \%$ relative to unburned sites (Fig. 2).

During the four-year study period, in the burned sites the rate of water permeability gradually recovered to the values in control sites. The calculation of the moisture reserves in the $0-30 \mathrm{~cm}$ layer showed similar moisture content and speed of water filtration dynamics of manifestation of a significant difference in the first two study years. It also demonstrated the alignment of the indicators by the end of the study period. It should be noted that the formation of a hydrophobic pyrogenic layer, the decrease in the speed of water filtration down the soil body and reserves of moisture are characteristics of soils of different natural zones. It is a universal consequence of fires (Shein et al., 2012; Shakhmatova, 2015).

The study of the granulometric soil composition showed a change in soil particles of the fine earth fraction of the upper soil layer $(0-10 \mathrm{~cm})$ under the fire influence. It was caused by a decrease in the content of clay and sand fractions with a maximum $(14.2 \%)$ and a significant $(\mathrm{U}=3.2$, at $\mathrm{p}=0.005)$ difference in the first year after the fire, and the smallest $(6.8 \%$ at the site of polygon 1 and $5.2 \%$ of polygon 2 ) after four years after the fire (Fig. 3). The change of the granulometric composition of the soil after the fire, a number of researchers associated with the movement of fine earth fraction down the surface of the soil and an increased risk of development of erosion processes (Vogelmann et al., 2013; Heydari et al., 2017). 


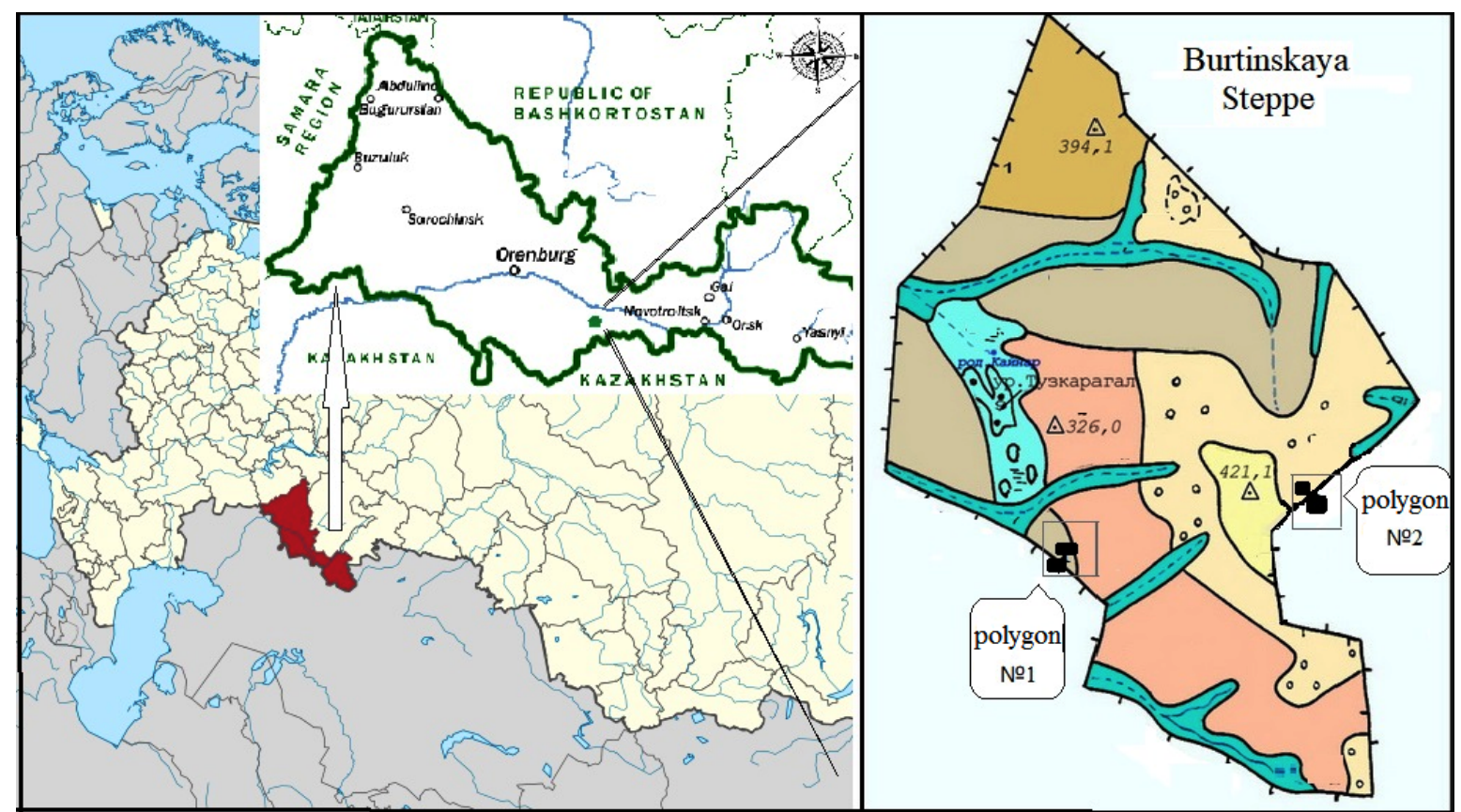

Fig. 1. The location of the site «Burtinskaya steppe» (Orenburg State Nature Reserve, Russia).
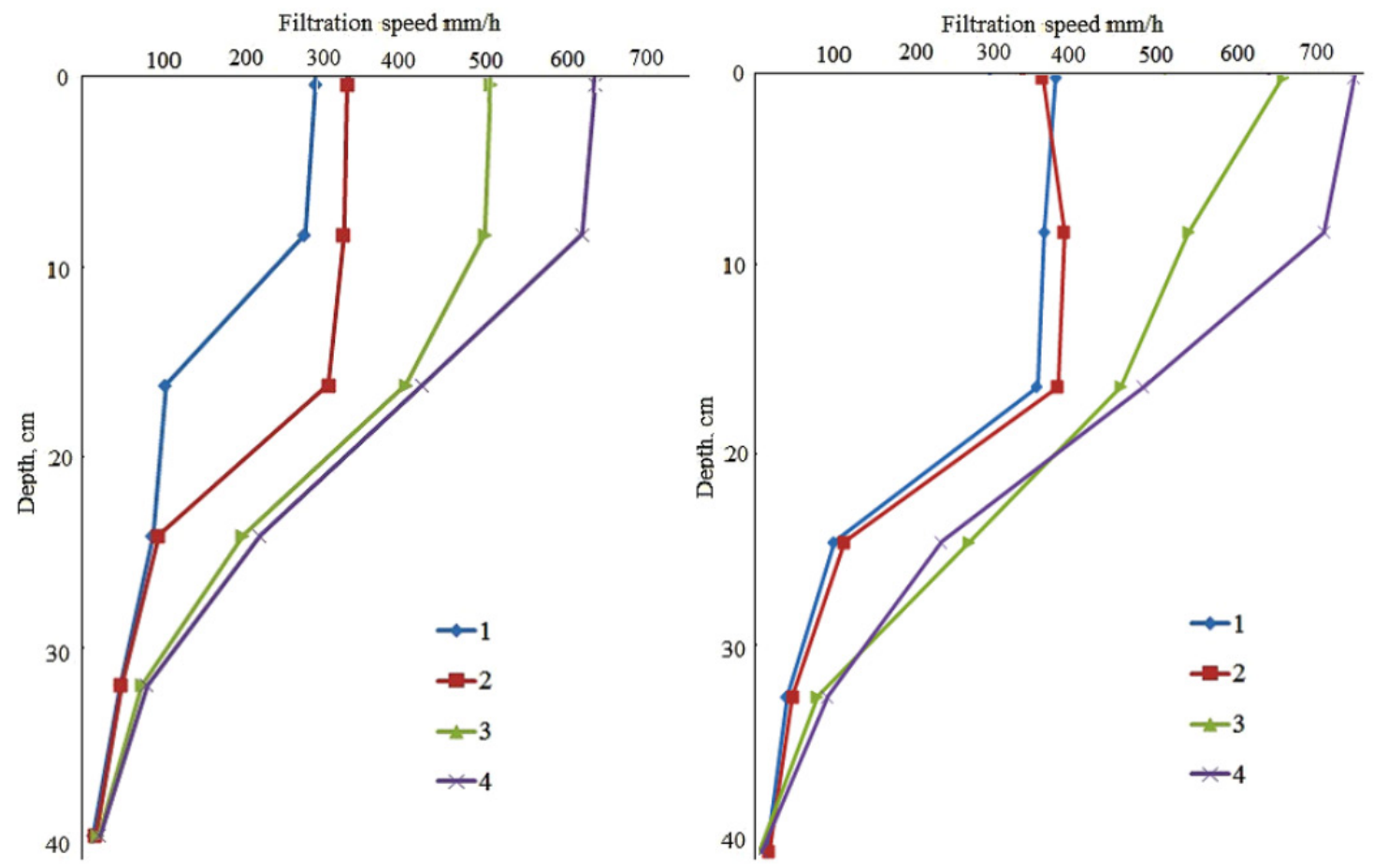

Fig. 2. Water filtration rate in soils in the study area. The period of twelve (left) and forty-eight (right) months after the fire influence. Note: 1 - unburned sites in polygon1;2-burned sites in polygon 1;3-unburned sites in polygon 2; 4 - burned sites in polygon 2 .

Changing the temperature and water balance in the fire-damaged sites led to a change in the chemical parameters of the soil (Table). Thus, the $\mathrm{pH}_{\mathrm{KCl}}$ index of soil solution had seasonal dynamics with a slight increase by the end of the growing season. The greatest variation of the indicator $(12.7 \%)$ was in the $0-10 \mathrm{~cm}$ soil layer in burned sites. Seasonal and annual dynamics of soil $\mathrm{pH}$ did not exceed 5\% in unburned sites. The described dynamics may be explained by the presence of gypsum in the soil mass composition. In the upper soil layer of poly- gon 1 , its content significantly exceeded the control soil by more than $9.5 \%(\mathrm{U}=3.2, \mathrm{p}=0.005)$.

The change of the complex chemical properties expressed in the variation of the values of cation exchange capacity from $33 \mathrm{mmol} / 100 \mathrm{~g}$ soil to $39 \mathrm{mmol} / 100 \mathrm{~g}$ soil in polygon 1 , and from 31 $\mathrm{mmol} / 100 \mathrm{~g}$ soil to $38 \mathrm{mmol} / 100 \mathrm{~g}$ soil in polygon 2 . The dynamics of the indicator in the upper layer was similar to the $\mathrm{pH}$. A significant impact of fire on the value of CEC was observed in the soils of the second polygon $(U=4.5$, at $p=0.005)$. 

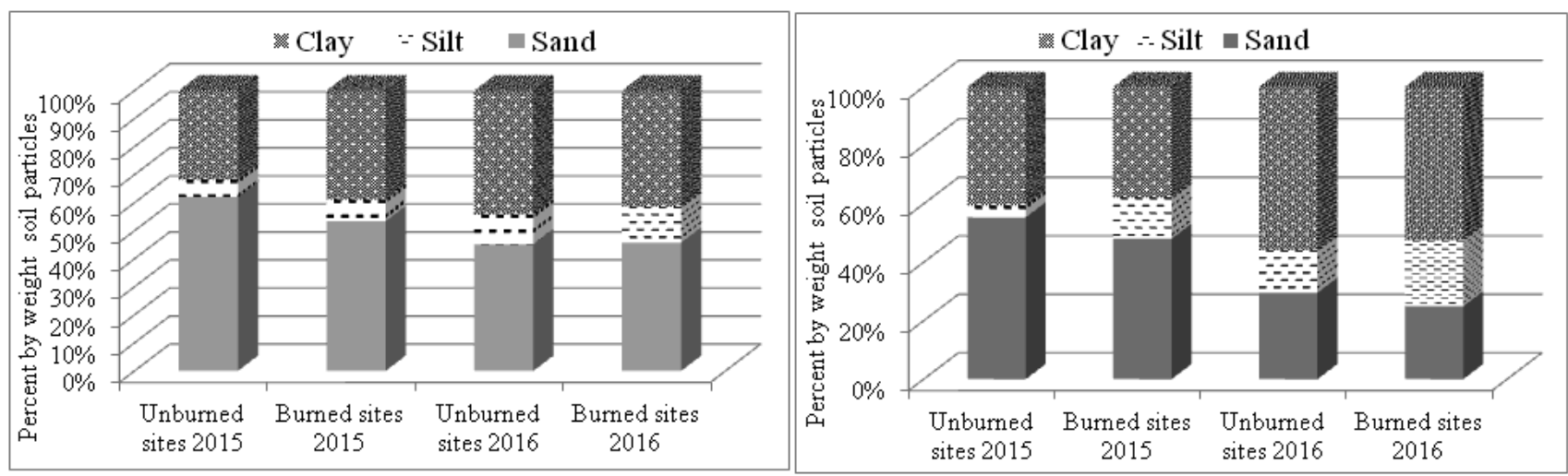

Fig. 3. The soil texture of polygon 1 (left) and polygon 2 (right) in the site «Burtinskaya steppe» of the Orenburg State Nature Reserve.

Table. The main soil properties in the sites studied in the first year after the fire influence

\begin{tabular}{|c|c|c|c|c|}
\hline \multicolumn{2}{|c|}{$\mathrm{pH}_{\mathrm{H} 2 \mathrm{O}}$} & $\mathrm{CEC}, \mathrm{mmol} / 100 \mathrm{~g}$ soil & $\mathrm{CaCO}_{3}, \%$ & $\mathrm{CaSO}_{4}, \%$ \\
\hline \multicolumn{7}{|c|}{ Polygon 1 (burned sites / unburned sites) } \\
\hline $0-5$ & $7.8 / 7.3$ & $39 / 33$ & $5.2 / 4.3$ & $0.170 / 0.052$ \\
\hline $5-10$ & $7.8 / 7.5$ & $37 / 35$ & $5.8 / 4.9$ & $0.173 / 0.059$ \\
\hline $10-20$ & $8.0 / 7.9$ & $29 / 27$ & $5.5 / 1.1$ & $0.186 / 0.147$ \\
\hline $20-30$ & $8.0 / 7.8$ & $27 / 27$ & $8.4 / 8.6$ & $0.192 / 0.192$ \\
\hline $30-50$ & $7.9 / 7.6$ & $23 / 21$ & $12.9 / 9.0$ \\
\hline \multicolumn{7}{|c|}{ Polygon 2 (burned sites / unburned sites) } \\
\hline $0-5$ & $7.6 / 7.0$ & $38 / 31$ & $1.5 / 1.2$ & $0.200 / 3.331$ \\
\hline $5-10$ & $7.3 / 6.9$ & $36 / 35$ & $1.2 / 1.1$ & $0.098 / 0.046$ \\
\hline $10-20$ & $7.4 / 7.0$ & $31 / 30$ & $8.0 / 2.9$ & $0.236 / 0.133$ \\
\hline $20-30$ & $7.2 / 7.2$ & $29 / 27$ & $16.3 / 8.8$ & $0.236 / 0.236$ \\
\hline $30-50$ & $7.2 / 7.3$ & $23 / 19$ & $15.7 / 8.7$ & $0.339 / 0.240$ \\
\hline
\end{tabular}

In the soils of the burned sites, there was a significant increase in the sodium content in the composition of the soil-absorbing complex by more than $16 \%$ and $7 \%$ in relation to the ones for unburned sites in the soils of polygon 1 and polygon 2 , respectively. Similar dynamics were observed for calcium carbonate with an increase in the concentration in the $0-5 \mathrm{~cm}$ layer by $20.9 \%$ and $25 \%$ in polygon 1 and polygon 2, respectively. By the end of the study period, the soils of site 1 differed significantly in terms of the set of chemical composition indicators. The tendency to increase the $\mathrm{pH}$ and change the CEC has been described also by Yildiz et al. (2010) and Shakhmatova (2015).

The study demonstrated that within a few months after the fire in the $0-10 \mathrm{~cm}$ soil layer, the total nitrogen content decreased by $43 \%$ in polygon 1 and by $39 \%$ in polygon 2 . The phosphorus content decreased by $19 \%$ and $32 \%$, potassium by $6 \%$ and $15 \%$ in the $0-10 \mathrm{~cm}$ soil layer in polygon 1 and polygon 2, respectively. Observations conducted in 2018 indicated an increase in the content of nitrogen, phosphorus and potassium in the soils of the burned sites in relation to the control values. The studies conducted in the first two years after the fire allowed recording a significant reduction of more than $12.6 \%$ (polygon 1 ) and $21.3 \%$ (polygon
2) of organic carbon in the $0-10 \mathrm{~cm}$ layer of burned soils. However, in the subsequent period, the humus content exceeded the control soil values by more than $6 \%$ in the soils of polygon 1 and by $15 \%$ in the soils of polygon 2 . The stabilisation of the carbon pool and the increase in the content of nutrients in the soil indicates the stability of the soilplant system in relation to the damaging effects of fire. This is in accordance with studies conducted in the forest-steppe and tropical soils (Yildiz et al., 2010; Vogelmann et al., 2013; Maksimova \& Abakumov, 2017). The same structure of organic matter on the results of infrared spectroscopy has not changed. This indicates a stabilisation of the soil organic matter accumulation and restoration of the carbon pool.

\section{Conclusions}

The impact of fires on the soils of the Orenburg State Nature Reserve manifested in a significant decrease in soil moisture, water filtration rate and soil moisture reserves at the first three years after the fire influence. Changes in water and heat regimes led to the intensification of soil accumulation of easily soluble salts and gypsum. In the damaged soils, there was a decrease in the content of organic substances, nitrogen, phosphorus and po- 
tassium in the first two years after the fire impact. However, the subsequent period was characterised by the level restoration of organic carbon and nitrogen above the soil of unburned sites.

The observed changes in soil granulometric composition are an important signal of the surface runoff development and reduced soil resistance to erosion processes.

The observed processes are dangerous from the viewpoint of preserving the appearance of protected areas. It indicates a need for in-depth and comprehensive study of the fire impact on the soils as a key link in the functioning of steppe ecosystems.

\section{References}

Coetsee C., Bond W.J., February E.C. 2010. Frequent fire affects soil nitrogen and carbon in an African savanna by changing woody cover. Oecologia 162(4): 1027-1034. DOI: 10.1007/s00442-009-1490-y

Heydari M., Rostamy A., Najafi F., Dey D.C. 2017. Effect of fire severity on physical and biochemical soil properties in Zagros oak (Quercus brantii Lindl.) forests in Iran. Journal of Forestry Research 28(1): 95-104. DOI: 10.1007/s11676-016-0299-x

IUSS Working Group WRB. 2015. International soil classification system for naming soils and creating legends for soil maps. World Soil Resources Reports No. Rome: FAO. №106. 216 p.

Jia X., Xie B., Shao M., Zhao C. 2015. Primary productivity and precipitation-use efficiency in temperate grassland in the Loess Plateau of China. PLoS ONE 10(8): e0135490. DOI: 10.1371/journal.pone.0135490

Klute A. (Ed.) 1986. Methods of soil analysis. Part 1-Physical and Mineralogical Methods. $2^{\text {nd }}$ Edition. Madison: WI Soil Science Society of America, American Society of Agronomy. 1188 p.

Krawchuk M.A., Moritz M.A., Parisien M.A., Van Dorn J., Hayhoe K. 2009. Global pyrogeography: the current and future distribution of wildfire. PLOS ONE 4(4): e5102. DOI: 10.1371/journal.pone.0005102

Leys B.A., Marlon J.R., Umbanhowar C., Vannière B. 2018. Global fire history of grassland biomes. Ecology and Evolution 8(17): 8831-8852. DOI: 10.1002/ece3.4394

Maksimova E., Abakumov E. 2017. Micromorphological characteristics of sandy forest soils recently impacted by wildfires in Russia. Solid Earth 8(2): 553-560. DOI: 10.5194/se-2016-173

Manning G.C., Baer S.G., Blair J.M. 2017. Effects of grazing and fire frequency on floristic quality and its relationship to indicators of soil quality in tallgrass prairie. Environmental Management 60(10): 1062-1075. DOI: 10.1007/s00267-017-0942-0

Pavleichik V.M., Kalmykova O.G., Soroka O.V. 2016. The features of microclimatic regime of the steppe burnt areas in the reserve «Burtinskaya steppe». Regional Environmental Issues 4: 69-74. [In Russian]

Rusanov A.M., Shein E.V. 2013. Modern evolution of soils and vegetation of agricultural lands of the Orenburg oblast. Moscow University Soil Science Bulletin 68(4): 180-184. DOI: 10.3103/S0147687413040042

Santín C., Doerr Sh. 2016. Fire effects on soils: the human dimension. Philosophical Transactions of the Royal Society B Biological Sciences 371(1696): 20150171 DOI: 10.1098/rstb.2015.0171

Shakhmatova E.Yu. 2015. Pyrogenicity - Response of Pine Forests Soils on Pyrogenic Factor Impact. International Journal of Applied and Fundamental Research 5(2): 260-264. [In Russian]

Shcherbyna V.V., Maltseva I.A., Maltsev Y.I., Solonenko A.N. 2017. Post-pyrogenic changes in vegetation cover and biological soil crust in steppe ecosystems. Regulatory Mechanisms in Biosystems 8(4): 663-668. DOI: $10.15421 / 021797$

Shein E.V., Rusanov A.M., Anilova L.V., Dostowa T.M. 2012. Water Regime Change Typical Chernozem the Formation of Surface Layer Pyrogens of Different Power. Vestnik of the Orenburg State University 10(146): 112-116. [In Russian]

Sparks D.L., Page A.L., Helmke P.A., Loeppert R.H. (Eds). 1996. Methods of Soil Analysis. Part 3 - Chemical Methods. Madison: WI Soil Science Society of America, American Society of Agronomy. 1390 p. DOI: 10.2136/sssabookser5.3.frontmatter

Vogelmann E.S., Reichert J.M., Prevedello J., Awe G.O. 2013. Hydro-physical processes and soil properties correlated with origin of soil hydrophobicity. Ciência Rural 43(9): 1582-1589. DOI: 10.1590/S0103-84782013005000107

Vorobieva L.A. 1998. Chemical analysis of soils. Moscow: Publisher of the Moscow State University. 272 p. [In Russian]

Yildiz O., Esen D., Sarginci M., Toprak B. 2010. Effects of forest fire on soil nutrients in Turkish pine (Pinus brutia, Ten) Ecosystems. Journal of Environmental Biology 31(1-2): 11-13. 


\author{
Л. В. Галактионова ${ }^{1,2}$, А. В. Васильченко ${ }^{3}$ \\ ${ }^{1}$ Федеральный научный иентр биологических систем и агротехнологий РАН, Россия \\ ${ }^{2}$ Оренбургский государственный университет, Россия \\ e-mail: anilova.osu@mail.ru \\ ${ }^{3}$ Тюменский государственный университет, Россия \\ e-mail:teslya_nastya@mail.ru
}

Особо охраняемые природные территории, расположенные в степной зоне России, представляют собой уникальные пространства, сохранившие облик степей Евразии. Пожары являются неотъемлемым фактором, влияющим на растительный и почвенный компоненты экосистем. Устойчивость почв к пожару в условиях полузасушливого климата и холмистого рельефа определяет скорость восстановления растительности и почв степного ландшафта. Исследование было посвящено изучению восстановления водно-физических, физико-химических и химических свойств почв после пожара в 2014 г. на участке «Буртинская степь» государственного заповедника «Оренбургский». Участки исследования были представлены двумя полигонами с соседними сожженными и несгоревшими (фоновыми) участками. Уничтожение растительности пожаром способствовало снижению запасов влаги в слое на 0-30 см более чем на $30 \%$ в первые годы после пожара. Для почв участков, пройденных пожаром, наблюдалось большее прогревание и миграция легкорастворимых солей и гипса в верхнюю часть почвенного профиля. Наиболее интенсивное накопление $\mathrm{CaSO}_{4}$ и солей натрия отмечено в почвах полигона 1. Изучение влияния пала на содержание в почве органического вещества и питательных веществ показало их значительное снижение в первые два года исследований. Восстановление содержания фосфора и калия до уровня фоновых участков отмечалось к концу трех лет наблюдений. А содержание в почве органического вещества и азота значительно превышало значения фоновых почв. Проведенное исследование позволило сделать вывод о способности почв степных ландшафтов к восстановлению запасов биогенных элементов после пожара. В то же время изменение гранулометрического состава и миграция почвенных солей вверх по профилю может способствовать перестройке растительных сообществ и изменению основных свойств почвенного покрова. Особая опасность смены почв степных ландшафтов возникает в условиях повторяющихся пожаров и изменения климата. Наблюдаемая постпирогенная динамика почвенных процессов свидетельствует о необходимости глубокого и всестороннего изучения воздействия пожаров на почву как ключевого звена в функционировании степных экосистем.

Ключевые слова: водно-физические свойства почв, гранулометрический состав, органический углерод, последствия пожаров, степные экосистемы, черноземы 